\title{
Free 2-Propen-1-amine Derivative and Inclusion Complexes with $\beta$-Cyclodextrin: Scanning Electron Microscopy, Dissolution, Cytotoxicity and Antimycobacterial Activity
}

\author{
Ana O. de Souza ${ }^{*, a}$, Rubens R. Santos-Jr ${ }^{a}$, Daisy N. Sato ${ }^{b}$, Marcelo M. M. de Azevedo ${ }^{c}$, Denise A. \\ Ferreira ${ }^{a}$, Patrícia S. Melo ${ }^{d}$, Marcela Haun ${ }^{d}$, Célio L. Silva and Nelson Durán ${ }^{c, e}$ \\ ${ }^{a}$ Departamento de Bioquímica e Imunologia, Faculdade de Medicina de Ribeirão Preto, Universidade de São Paulo, \\ Avenida Bandeirantes, 3900, 14049-900 Ribeirão Preto-SP, Brazil \\ ${ }^{b}$ Instituto Adolfo Lutz, Rua Minas 877, 14085-410 Ribeirão Preto-SP, Brazil \\ ${ }^{c}$ Instituto de Química and ${ }^{d}$ Instituto de Biologia, Universidade Estadual de Campinas, 13083-970, Campinas-SP, Brazil \\ ${ }^{e}$ NCA, Universidade de Mogi das Cruzes, 08780-911, Mogi das Cruzes-SP, Brazil
}

\begin{abstract}
Complexos de inclusões e misturas físicas contendo mistura isomérica $E / Z$ (50:50) de 3-(4'bromo-[1,1'-bifenil]-4-il)-3-(4-bromofenil)-N,N-dimetil-2-propen-1-amina (BBAP) e $\beta$-ciclodextrina $(\beta$-CD) nas proporções molares de 1:1 e 1:2 foram analisados por microscopia eletrônica de varredura (SEM). O perfil de dissolução do BBAP e dos complexos de inclusões foram também avaliados durante 6 horas. Por microscopia eletrônica de varredura foi possível observar os complexos de inclusões formados entre BBAP e $\beta$-CD por co-evaporação nas proporções molares de 1:1 e 1:2. Como previamente detectado pela caracterização físico-química, na mistura física não se observou a presença de complexo de inclusão. Os estudos de dissolução mostraram que os complexos de inclusões 1:1 e 1:2 liberaram, respectivamente $49.07 \pm 1.48$ e $40.26 \pm 3.90 \%$ de BBAP durante 6 horas. BBAP na forma livre foi menos solúvel que os complexos de inclusões e atingiu $9.00 \pm 0.75 \%$ de dissolução. Os ensaios de citotoxicidade em macrófagos J774 e em uma linhagem de células fibroblásticas de pulmão (V79) indicaram que o BBAP não exibiu efeito tóxico adicional quando complexado com $\beta$-CD. Entretanto, os complexos de inclusões foram menos tóxicos para células V79 que BBAP na forma livre. Os complexos de inclusões BBAP/ $\beta$-CD foram mais efetivos (CIM) que o composto livre em várias cepas de micobactérias. Resultados semelhantes foram observados sobre $M$. tuberculosis H37Rv intracelular para os complexos de inclusões BBAP/ $\beta-\mathrm{CD}$ e rifampicina, uma droga antituberculose de primeira linha.
\end{abstract}

Inclusion complexes and physical mixtures of isomeric mixture of $E / Z$ (50:50) of 3-(4'-bromo[1,1'-biphenyl]-4-yl)-3-(4-bromophenyl)-N,N-dimethyl-2-propen-1-amine (BBAP) and $\beta$-cyclodextrin $(\beta$-CD) in the molar proportion of $1: 1$ and $1: 2$ were analyzed by scanning electron microscopy. The dissolution behavior of BBAP and of the inclusion complexes were also evaluated for six hours. By scanning electron microscopy (SEM), it was possible to observe an inclusion complex formed between BBAP and $\beta$-CD by co-evaporation, either in the molar proportion of $1: 1$ or $1: 2$. In the physical mixtures, no complex was observed as previously detected by physicochemical analysis. The dissolution studies showed that the inclusion complexes BBAP/ $\beta$-CD 1:1 and 1:2 released respectively $49.07 \pm 1.48$ and $40.26 \pm 3.90 \%$ of BBAP during six hours. Free BBAP was less soluble than the inclusion complex and reached $9.00 \pm 0.75 \%$ of dissolution. Biological assays, such as cytotoxicity to J774 macrophages and to a permanent lung fibroblast cell line (V79), indicated that the BBAP does not exhibit any additional toxic effect with the $\beta$-CD complexes. However, the complexes were less cytotoxic to V79 cells than the free form. The BBAP/ $\beta$-CD inclusion complexes were more effective (MIC) than the free compound on several mycobacteria strains. Similar behavior was observed for BBAP $/ \beta$-CD complexes and rifampicin, a front-line antitubercular drug, on $M$. tuberculosis $\mathrm{H} 37 \mathrm{Rv}$ growing inside $\mathrm{J} 774$ macrophages.

Keywords: inclusion complexes, cytotoxicity, antimycobacterial activity

\footnotetext{
*e-mail: olivia@cpf.fmrp.usp.br
} 


\section{Introduction}

CDs are cyclic oligosaccharides named $\alpha, \beta$ and $\gamma-\mathrm{CD}$, and have a relatively hydrophobic central cavity and a hydrophilic outer surface. There has been great interest in $\mathrm{CD}$ inclusion complexes, as a means of increasing the solubility and dissolution rate of poorly soluble drugs. Water-insoluble drugs are usually characterized by a low bioavailability, since their absorption is dissolution ratelimited and consequently slow. CDs were considered good candidates for the enhancement of the dissolution rate of insoluble drugs. ${ }^{1}$

As previously reported, ${ }^{2-6}$ among ten 2-propen-1-amine derivatives, 3-(4'-Bromo-[1,1'-biphenyl]-4-yl)-3-(4bromophenyl)-N,N-dimethyl-2-propen-1-amine (BBAP), is a compound with promising pharmacological activities against pathogenic trypanosomatids and mycobacteria. However, it presents the disadvantages of toxicity towards mammalian cells and no solubility in water. In order to improve the solubility of BBAP, inclusion complex and physical mixture containing BBAP (as a mixture of geometric isomers) and $\beta$-CD were previously prepared and physicochemically characterized. An inclusion complex was obtained between BBAP and $\beta$-CD after coevaporation, and no inclusion complex was formed in the physical mixture. ${ }^{7}$

In this study, the morphology of the inclusion complex and of the physical mixture between BBAP and $\beta$-CD were analyzed by scanning electron microscopy (SEM). The solubility of BBAP was evaluated in presence of different concentrations of $\beta$-CD and the extension of dissolution in water of the inclusion complexes was determined. Biological assays were also performed in order to evaluate the cytotoxicity of the inclusion complexes and the antimycobacterial activity.

\section{Materials and Methods}

\section{Materials}

$\beta$-CD was purchased from Sigma and the ethanol used was of analytical grade. Inclusion complexes and physical mixtures were prepared and physicochemically characterized following the procedure previously described. ${ }^{7}$ Briefly, BBAP (as a mixture of geometric isomers 50:50) and $\beta$-CD in the molar proportion of $1: 1$ and 1:2 were dissolved in a mixture of water/ethanol (30:100) and the solvent was evaporated at $80^{\circ} \mathrm{C}$ under reduced pressure. Physical mixtures of BBAP and $\beta$-CD in the molar proportion of 1:1 and 1:2 were uniformly and gently mixed without milling in order to avoid any grinding action in the mixture. BBAP, inclusion complexes and the physical mixture were completely dried under high vacuum at room temperature and stored in a desiccator over silica gel until the moment of use.

\section{Scanning electron microscopy}

Scanning Electron Microscopy (SEM) of the BBAP, $\beta$ $\mathrm{CD}$, physical mixtures (BBAP/ $\beta$-CD 1:1 and 1:2), and of the inclusion complexes (BBAP/ $\beta$-CD 1:1 and 1:2) were performed using a JEOL JSM - T300 microscope in order to obtain the topographic images, through secondary electrons with a tension of $20 \mathrm{KV}$. Samples were mounted using double-sided adhesive coated aluminum stubs and vacuum-coated with gold for 100 seconds to render them electrically conductive.

\section{Phase solubility studies}

The phase solubility studies were performed according to the method reported by Higuchi and Connors. ${ }^{8}$ BBAP $(5 \mathrm{mg})$ was added to the aqueous solution $(10 \mathrm{~mL})$ containing different concentrations of $\beta$ - $\mathrm{CD}(0,0.2,0.4$, $0.6,0.8,1.0,1.2,1.4,1.6$ and $\left.1.8 \mathrm{mmol} \mathrm{L}^{-1}\right)$. The experiments were carried out in triplicate. Solutions were shaked at $25{ }^{\circ} \mathrm{C}$ for 48 hours. This time of reaction was chosen from preliminary kinetic studies (not shown). After that, the suspensions were filtered through a $0.22 \mu \mathrm{m}$ Millipore glass fiber membrane filter, and the concentration of BBAP in the filtrate was determined by spectrophotometer at $266 \mathrm{~nm}$.

The apparent 1:1 stability constant (Ks) was calculated from the straight line of the phase-solubility diagram, following the equation proposed by Higuchi and Connors: $\mathrm{Ks}=$ slope/intercept (1-slope), where $S_{\mathrm{o}}$ is the BBAP equilibrium concentration in aqueous solution in the absence of $\beta-\mathrm{CD}$, and slope is the slope of the phase solubility diagram.

\section{Dissolution studies}

The dissolution behavior of both, BBAP/ $\beta-\mathrm{CD} 1: 1$ and BBAP $/ \beta$-CD 1:2 complexes were compared with that of pure BBAP. Tests were carried out according to USP23 Method. The dissolution media was deionized water, the stirring speed was $50 \mathrm{rpm} / \mathrm{min}$ and the temperature was maintained at $37{ }^{\circ} \mathrm{C}$ and the samples were stirred for six hours. The amount of each binary system employed followed the molar ratio $1: 1$ and 1:2. Aliquots of $2 \mathrm{~mL}$ were withdrawn at various time intervals, filtered through a $0.22 \mu \mathrm{m}$ membrane filter and immediately replaced with 
an equal volume of water. The amount of BBAP dissolved was appropriately diluted in ethanol and the concentration was determined by spectrophotometry at $266 \mathrm{~nm}$.

BBAP concentration was determined by comparison with a standard curve of BBAP in ethanol. The measurements were evaluated in duplicate in two independent assays. A correction was applied to compensate the cumulative dilution caused by replacement of water to the samples.

\section{Biological assays}

Extracellular antimicrobial susceptibility testing. Tests were performed by the microplate Alamar Blue assay, as previously described. ${ }^{9}$ M. tuberculosis H37Rv ATCC 27294, M. tuberculosis H37Ra ATCC 25177, M. avium ATCC 15769, M. kansasii ATCC 12478, M. intracellulare ATCC 25169, and M. malmoense ATCC 29571 were grown in Loweinstein-Jensen medium at $37^{\circ} \mathrm{C}$ for 3 weeks and subcultured in Middlebrook $7 \mathrm{H} 9$ broth medium at $37^{\circ} \mathrm{C}$ for 10 days, until a 1.0 McFarland turbidity standard was reached. Suspensions of mycobacteria were diluted 1:25 in Middlebrook $7 \mathrm{H} 9$ broth medium and $100 \mu \mathrm{L}$ were seeded in a 96-well microplate $\left(4 \times 10^{5}\right.$ mycobacteria $\left.\mathrm{mL}^{-1}\right)$ containing $100 \mu \mathrm{L}$ of serial dilutions of the samples. Plates were incubated at $37^{\circ} \mathrm{C}$ for 6 days. Following that, $25 \mu \mathrm{L}$ of a mixture 1:1 (v/v) of Alamar Blue reagent and $10 \%$ Tween 80 were added to the wells and plates were reincubated at $37^{\circ} \mathrm{C}$. After 24 hours, a change in color, from blue to pink, was observed in the wells where mycobacteria grew. Solutions of the samples were prepared in dimethylsulfoxide (DMSO - Sigma Chem. Co, MO, USA) and sterilized by passage through a $0.22 \mu \mathrm{m}$ PFTE filter. Dilutions in the range from 0.001 to $0.640 \mathrm{mmol} \mathrm{L}^{-1}$ were performed in Middlebrook $7 \mathrm{H} 9$ broth medium with the final concentration of DMSO never exceeding $0.3 \%$. Rifampicin was used as reference drug. Control wells consisted of either bacterium only, drugs with medium or only medium. The visual MICs were defined as the lowest drug concentration that prevented a color change from blue to pink.

Intracellular Antimicrobial susceptibility testing. J774 macrophages were harvested and plated at a concentration of $5 \times 10^{5}$ cells per well in 24-well tissue culture plates. After overnight incubation, J774 macrophages were overlaid with a suspension of $M$. tuberculosis $\mathrm{H} 37 \mathrm{Rv}\left(5 \times 10^{6}\right.$ mycobacteria $\mathrm{mL}^{-1}$ ) adjusted to yield a multiplicity of infection of 10 bacteria per macrophage. Cells were infected for 4 hours and washed with phosphate-buffered saline (PBS), pH 7.4, to eliminate unbound mycobacteria. ${ }^{10} \mathrm{M}$. tuberculosis H37Rv-infected cells were re-fed with culture medium and then incubated with different concentrations of the samples ranging from 0.001 to $0.080 \mathrm{mmol} \mathrm{L}^{-1}$. Rifampicin at 0.012 mmol L-1 and RPMI 1640 medium were used as controls. After $72 \mathrm{~h}$, cells were washed with culture medium to eliminate extracellular bacteria and lysed by addition of 1 $\mathrm{ml}$ of $0.25 \%(\mathrm{~m} / \mathrm{v})$ sodium dodecyl sulfate in PBS, pH 7.4. The lysates were serially diluted and $100 \mu \mathrm{L}$ aliquots were dispersed onto 7H10 agar plates. The colony formation units (CFU) of M. tuberculosis H37Rv were counted 2-4 weeks after incubation at $37^{\circ} \mathrm{C}$.

Cytotoxicity to mammalian cells. Cytotoxicity of the preparations was determined by a multi-endpoint method. The cytotoxic effect, expressed as cell viability, was assayed on $\mathrm{J} 774$ macrophages and in a permanent lung fibroblast cell line derived from Chinese hamsters (V79).

Stock solutions of the samples were prepared in DMSO, and diluted in Dulbecco's modification of Eagle's medium (DMEM) or RPMI 1640 medium without phenol red. The final concentration of the solvent in the assay was less than $0.3 \%$. The controls received no drugs and each drug concentration was tested in six (J774 cells) or eight replicates (V79 cells), and repeated three times in separate experiments. After 24 hours of incubation, three independent endpoints for cytotoxicity were evaluated: nucleic acid content (NAC), reduction of 3-(4,5dimethylthiazole-2-yl)-2,5-diphenyl tetrazolium bromide (MTT), and neutral red uptake (NRU).

J774 Cells: J774 cells were grown as monolayers in RPMI 1640 medium supplemented with 10\% heatinactivated fetal calf serum (FCS), $100 \mathrm{IU} \mathrm{mL}^{-1}$ penicillin and $100 \mu \mathrm{g} \mathrm{mL}^{-1}$ streptomycin in a humidified incubator with $5 \% \mathrm{CO}_{2}$ in air at $37^{\circ} \mathrm{C}$. Cells were plated in 96-well plates at the concentration of $2 \times 10^{6}$ cells $\mathrm{mL}^{-1}$. The medium was removed 12 hours after cell seeding and replaced by a medium containing the samples at concentrations ranging from 0 to $0.160 \mathrm{mmol} \mathrm{L}^{-1}$. Cells were exposed for 24 hours to test medium with or without the drugs (control).

V79 Fibroblasts: V79 fibroblasts were grown as monolayers in Dulbecco's modification of Eagle's medium (DMEM), supplemented with $10 \%$ heat-inactivated fetal calf serum (FCS), $100 \mathrm{IU} \mathrm{mL} \mathrm{mL}^{-1}$ penicillin and $100 \mu \mathrm{g} \mathrm{mL}^{-1}$ streptomycin in a humidified incubator with $5 \% \mathrm{CO}_{2}$ in air at $37^{\circ} \mathrm{C}$. Cells were plated at the density of $3 \times 10^{4}$ cells $\mathrm{mL}^{-1}$ in 96 -well plates. The medium was removed 48 hours after cell seeding and replaced with medium containing the samples at concentrations ranging from 0 to $0.060 \mathrm{mmol} \mathrm{L}^{-1}$. Samples were first dissolved in DMSO and then diluted in DMEM. Cells were exposed for 24 hours to test medium with or without drugs (control).

NAC: The cell number in control and treated wells was estimated from their total nucleic acid content according 
to Cingi et al. ${ }^{11}$ After exposition to samples, the cells were washed twice with cold PBS, $\mathrm{pH}=7.4$, and a soluble nucleotide pool was extracted with cold ethanol. Cell monolayers were then dissolved in $0.1 \mathrm{~mL}$ of $\mathrm{NaOH}(0.5$ mol L-1) and incubated at $37^{\circ} \mathrm{C}$ for 1 hour and absorbance was read at $260 \mathrm{~nm}$. The results are expressed by comparison of absorbance between cells treated with drugs and controls (no drugs).

MTT: The tetrazolium reduction assay was performed according to Denizot and Lang. ${ }^{12}$ Briefly, after exposition to the drugs, cells were washed once with PBS, $\mathrm{pH}=7.4$, and $0.1 \mathrm{~mL}$ of serum-free medium containing MTT $(1 \mathrm{mg}$ $\mathrm{mL}^{-1}$ for V79 cells and $0.5 \mathrm{mg} \mathrm{mL}^{-1}$ for $\mathrm{J} 774$ cells) was added to each well. After incubation for $4 \mathrm{~h}$, the supernatant was removed and the blue formazan product obtained was dissolved in $0.1 \mathrm{~mL}$ of ethanol for V79 cells and $0.1 \mathrm{~mL}$ of isopropanol acid $\left(\mathrm{HCl} 0.1 \mathrm{~mol} \mathrm{~L}^{-1}\right)$ for $\mathbf{J} 774$ cells. Plates were stirred for $15 \mathrm{~min}$ on a microtiter plate shaker and absorbance was read at $570 \mathrm{~nm}$.

NRU: The neutral red uptake assay was performed according to Borenfreund and Puerner. ${ }^{13}$ After exposition to the drugs, cells were incubated for 4 hours with serumfree medium containing neutral red $\left(50 \mu \mathrm{g} \mathrm{mL}^{-1}\right)$ and then quickly washed with PBS-Ca ${ }^{2+}$ (PBS plus $1 \mathrm{mmol} \mathrm{L}^{-1}$ of $\mathrm{CaCl}_{2}$ and $2 \mathrm{mmol} \mathrm{L}^{-1}$ of $\left.\mathrm{MgCl}_{2}\right), \mathrm{pH}$ 7.4. The dye was dissolved in $0.1 \mathrm{~mL}$ of $1 \%(\mathrm{v} / \mathrm{v})$ acetic acid in $50 \%(\mathrm{v} / \mathrm{v})$ ethanol and, after agitation on a microtiter plate shaker, absorbance was read at $540 \mathrm{~nm}$.

\section{Results and Discussion}

\section{Scanning electron microscopy}

In the morphological analysis, typical crystals of $\beta-\mathrm{CD}$ were found in many different sizes (Figure 1A). BBAP showed a wavy domain by SEM (Figure 1B) and an amorphous one by $\mathrm{X}$-ray diffraction. There was an agglomeration of $\beta$-CD around the BBAP in the physical mixtures of BBAP $/ \beta-\mathrm{CD}$ 1:1 (Figure 2A) and 1:2 (Figure 3A). Regarding the coevaporated inclusion complex BBAP/ $\beta$-CD 1:1 (Figure 2B) and 1:2 (Figure 3B), a compact structure formed by the aggregation of the crystals was observed. Whereas the physical mixture showed the crystalline structure of BBAP and $\beta-\mathrm{CD}$, the features of both crystals in the inclusion complex were not easily detectable. Scanning electron microscopy revealed morphological differences among the different preparations, contributing to the characterization of the physical mixtures and of the inclusion complexes BBAP/ $\beta$-CD $1: 1$ and $1: 2$. These data are in agreement with previous results, ${ }^{7}$ showing the presence of inclusion complex between BBAP and $\beta$-CD.
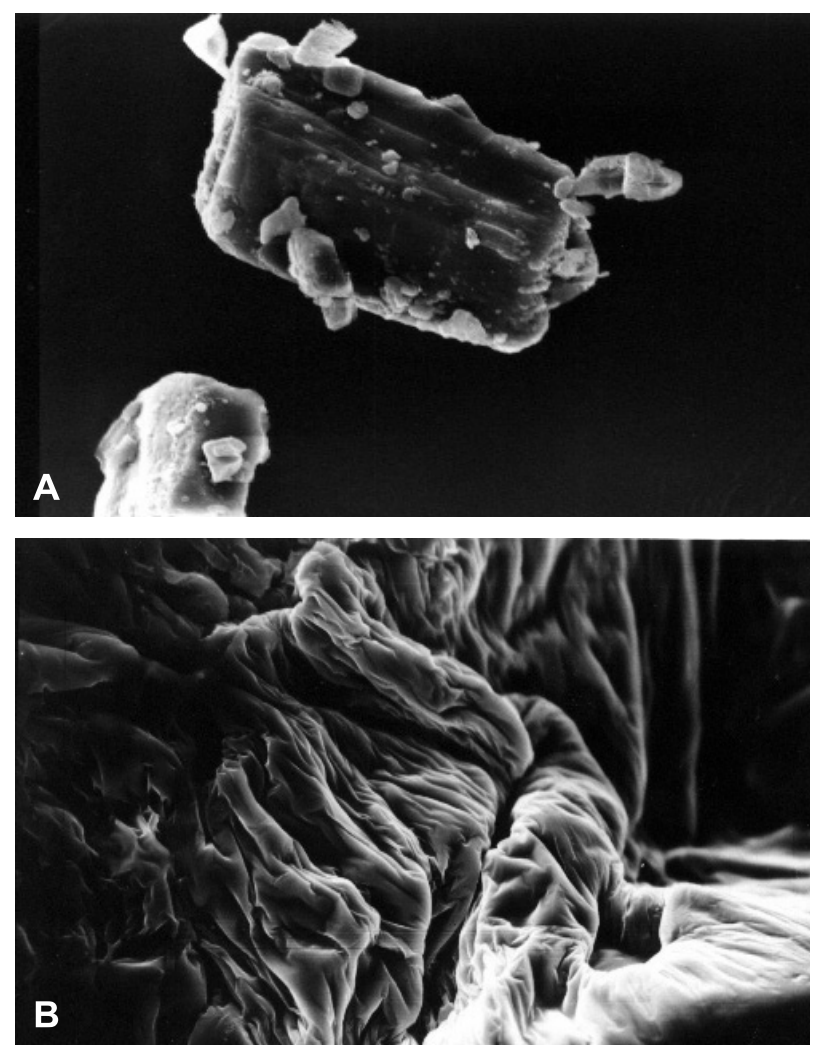

Figure 1. Scanning electron microscopy of $\beta$-CD (A) and BBAP (B) - Magnification of 750X.
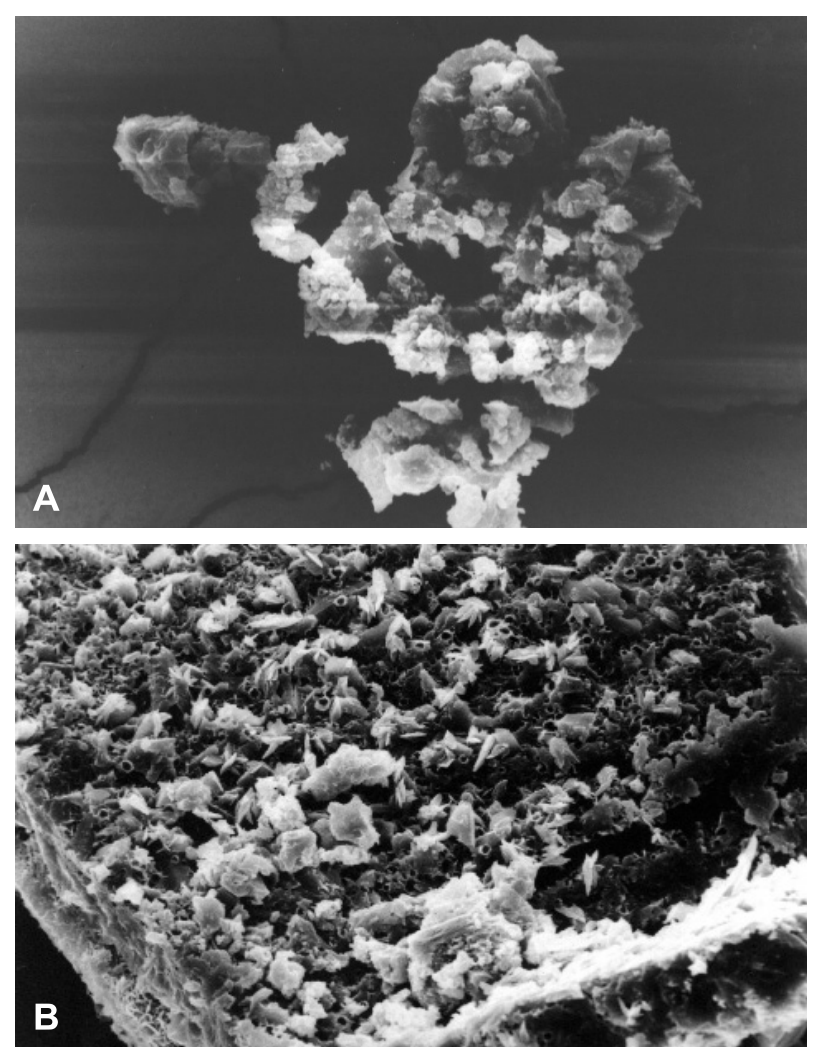

Figure 2. Scanning electron microscopy of physical mixture BBAP/ $\beta$-CD 1:1 (A) and inclusion complex of BBAP/ $\beta$-CD 1:1 (B) - magnification of $750 \mathrm{X}$. 

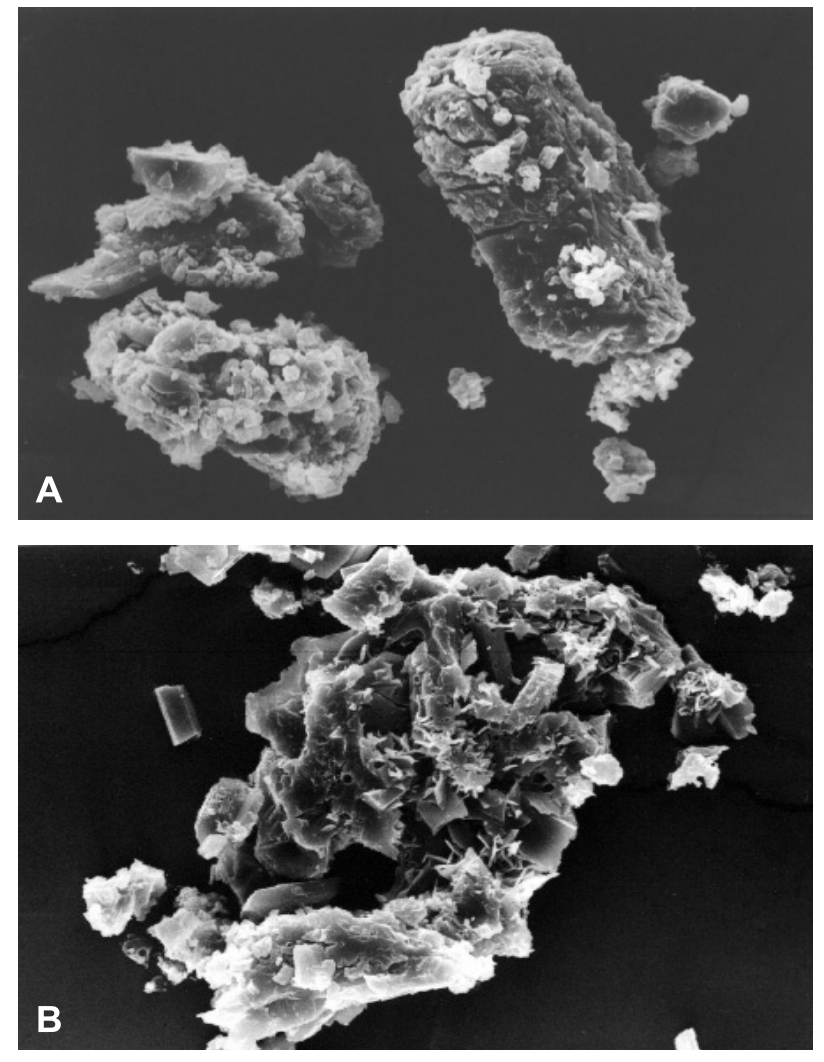

Figure 3. Scanning electron microscopy of physical mixture BBAP/ $\beta$-CD 1:2 (A) and inclusion complex BBAP/ $\beta$-CD 1:2 (B) - magnification of $750 \mathrm{X}$.

\section{Phase solubility studies}

The phase solubility diagram for BBAP with $\beta$-CD is shown in Figure 4. In the presence of $\beta$-CD the phase solubility behavior of BBAP followed the $\mathrm{A}_{\mathrm{L}}$ - type phase solubility diagrams ${ }^{8}$ and suggests $1: 1$ interaction between $\mathrm{BBAP}$ and $\beta$-CD. The Ks value obtained was $16.75 \mathrm{M}^{-1}$ to $\beta$-CD, indicating a weak interaction between BBAP and $\beta-\mathrm{CD}$.

\section{Dissolution studies}

Dissolution profiles were not performed for the physical mixtures, since there is no inclusion complex in these preparations. Figure 5 shows the dissolution behavior of BBAP and of its inclusion complexes with $\beta$-CD. In the end of the experiment, the percentage of dissolved BBAP reached $9.00 \pm 0.75 \%$. The inclusion complexes $\mathrm{BBAP} / \beta-\mathrm{CD} 1: 1$ and $1: 2$ showed a similar dissolution behavior, with respectively $49.07 \pm 1.48$ and $40.26 \pm$ $3.90 \%$ dissolution. At the molar proportion of $1: 1$, dissolution was higher than at 1:2. Dissolved amounts of BBAP from the inclusion complex in the molar proportion of $1: 1$ and $1: 2$ increased respectively 5.45 and 4.47 -fold,

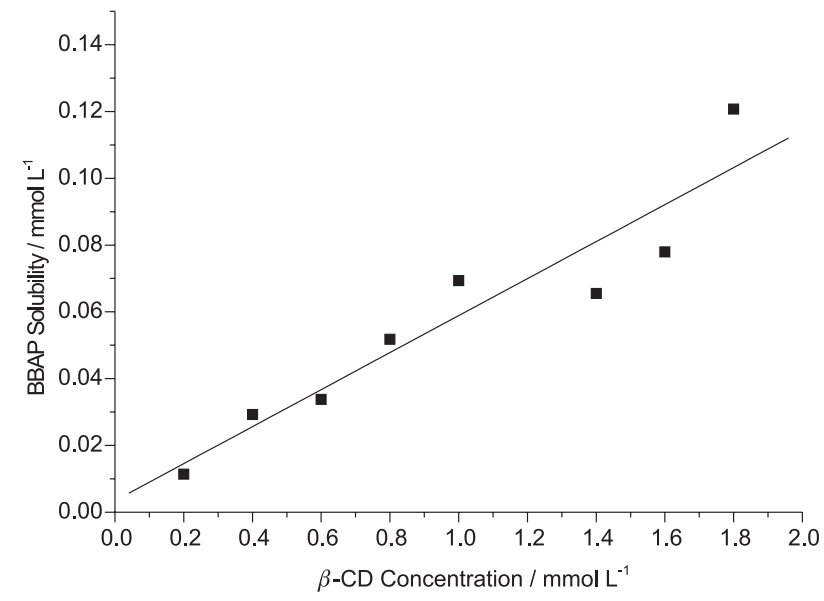

Figure 4. Solubility of BBAP in water at $25^{\circ} \mathrm{C}$ as a function of $\beta$-CD concentration.

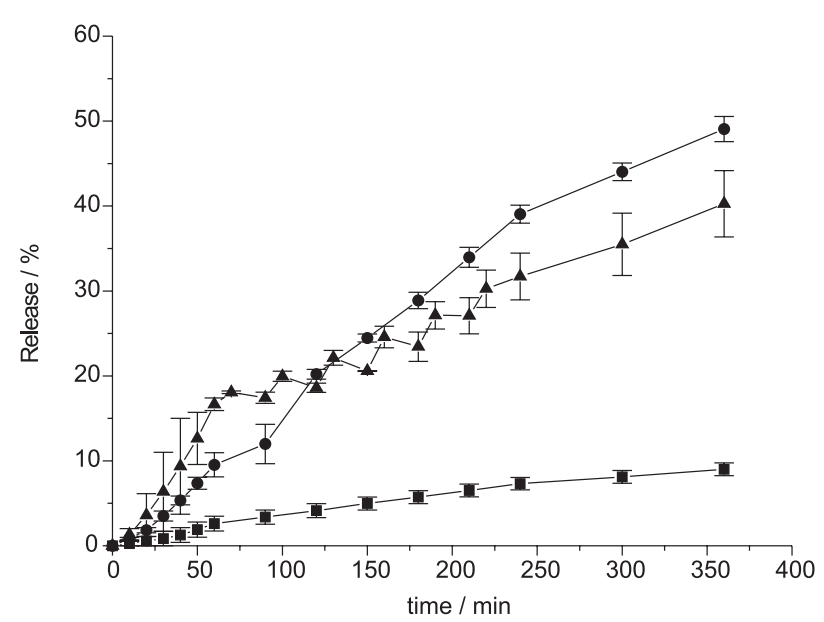

Figure 5. Dissolution profiles of BBAP $(\mathbf{\square}), \mathrm{BBAP} / \beta-\mathrm{CD} 1: 1$

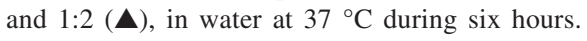

compared with pure BBAP at six hours. In these preparations, $\beta$-CD increased the ability of dissolution of BBAP, as expected.

\section{Biological assays}

Extracellular antimicrobial susceptibility testing. Table 1 shows the minimal inhibitory concentration (MIC) of BBAP and of the inclusion complexes BBAP $/ \beta-C D$ D $1: 1$ and 1:2 against mycobacteria. Either free BBAP or BBAP complexed with $\beta$-CD acting on M. tuberculosis $\mathrm{H} 37 \mathrm{Rv}$ showed the same activity, with MIC around $0.008 \mathrm{mmol} \mathrm{L}^{-1}$. However, on M. tuberculosis H37Ra, M. avium and M. kansasii, both 1:1 and 1:2 complexes were at least four times more effective than the free form of BBAP. Regarding M. intracellulare, an 8-fold higher activity was observed in comparison to the free form. A slight difference was observed with M. malmoense (1.6 fold) compared with the free form. 
Table 1. MICs $\left(\mathrm{mmol} \mathrm{L}^{-1}\right)$ of BBAP, inclusion complex BBAP/ $\beta$-CD $1: 1$ and $1: 2$ on standard mycobacterial strains

\begin{tabular}{lccc}
\hline & \multicolumn{3}{c}{ Samples $\left(\mathrm{mmol} \mathrm{L}^{-1}\right)$} \\
Strains & BBAP & $\begin{array}{c}\text { BBAP } / \beta-\mathrm{CD} \\
1: 1\end{array}$ & $\begin{array}{c}\text { BBAP } / \beta-\mathrm{CD} \\
1: 2\end{array}$ \\
\hline M. tuberculosis $\mathrm{H} 37 \mathrm{Rv}$ & 0.008 & $\leq 0.008$ & $\leq 0.008$ \\
M. tuberculosis $\mathrm{H} 37 \mathrm{Ra}$ & 0.032 & $\leq 0.008$ & $\leq 0.008$ \\
M avium & 0.032 & $\leq 0.008$ & $\leq 0.008$ \\
M. kansasii & 0.032 & $\leq 0.008$ & $\leq 0.008$ \\
M. intracellulare & 0.064 & $\leq 0.008$ & $\leq 0.008$ \\
M. malmoense & 0.016 & $\leq 0.010$ & $\leq 0.010$ \\
\hline
\end{tabular}

M. tuberculosis H37Rv ATCC 27294, M. tuberculosis H37Ra ATCC 25177, $M$ avium ATCC 15769, M. kansasii ATCC 12478, M. intracellulare ATCC 25169, M. malmoense ATCC 29571.

Intracellular antimicrobial susceptibility testing. Figure 6 shows the effect of free BBAP and of the inclusion complexes BBAP/B-CD 1:1 or 1:2 and rifampicin, against M. tuberculosis $\mathrm{H} 37 \mathrm{Rv}$ growth inside $\mathrm{J} 744$ macrophages. Free BBAP significantly reduced the CFU number at 0.080 mmol L-1. Complex 1:1 reduced the CFU number; however this effect was not significant in all the concentrations assayed. BBAP/ $\beta$-CD 1:2 at $0.080 \mathrm{mmol} \mathrm{L}^{-1}$ showed a significant effect, similar to that of rifampicin at $0.012 \mathrm{mmol} \mathrm{L}^{-1}$.

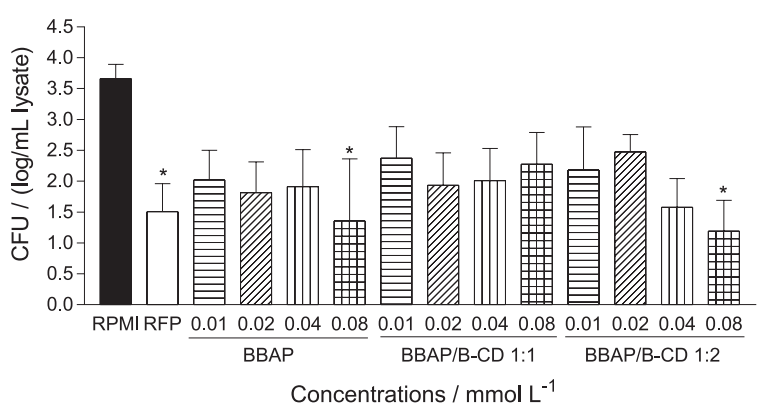

Figure 6. Effects of free BBAP and of inclusion complexes BBAP/ $\beta$-CD 1:1 or BBAP/ $\beta$-CD 1:2 and RFP against $M$. tuberculosis H37Rv growth inside J774 macrophages. Macrophages were lysed to determine the CFU of M. tuberculosis $\mathrm{H} 37 \mathrm{Rv}$ following the procedure described in the text. Bars represent mean \pm SEM. RPMI 1640 and Rifampicin (RFP - $0.012 \mathrm{mmol} \mathrm{L}^{-1}$ ) were used as controls.

Cytotoxicity to mammalian cells. Figure 7 shows the cytotoxicity of free and inclusion complexes of BBAP/ $\beta$ CD 1:1 and 1:2 on V79 cells by multi-endpoints NAC, MTT and NR, respectively. In Figure 7A, it may be observed that neither the $1: 1$ nor the $1: 2 \mathrm{BBAP} / \mathrm{B}-\mathrm{CD}$ complexes presented significant cytotoxicity (only $10 \%$ of reducing viability at $0.060 \mathrm{mmol} \mathrm{L}^{-1}$ ), however the free form was extremely toxic in the nucleic acid content (NAC) test $\left(\mathrm{IC}_{50}\right.$ of $\left.0.008 \mathrm{mmol} \mathrm{L}^{-1}\right)$. Similar results were observed in the neutral red (NR) test (Figure 7C), which showed an $\mathrm{IC}_{50}$ of $0.011 \mathrm{mmol} \mathrm{L}^{-1}$ in the free form and absence of cytotoxic effect in the complexes. In the MTT assay (Figure $7 \mathrm{~B}), \mathrm{BBAP} / \beta$-CD complex induced a strong enhancement in MTT reduction, but BBAP was very toxic in its free form $\left(\mathrm{IC}_{50} 0.005 \mathrm{mmol} \mathrm{L}^{-1}\right)$. Some authors ${ }^{14,15}$ have suggested that MTT reduction is a measurement of mitochondrial function, in particular of succinate dehydrogenase activity, but studies using hepatocytes
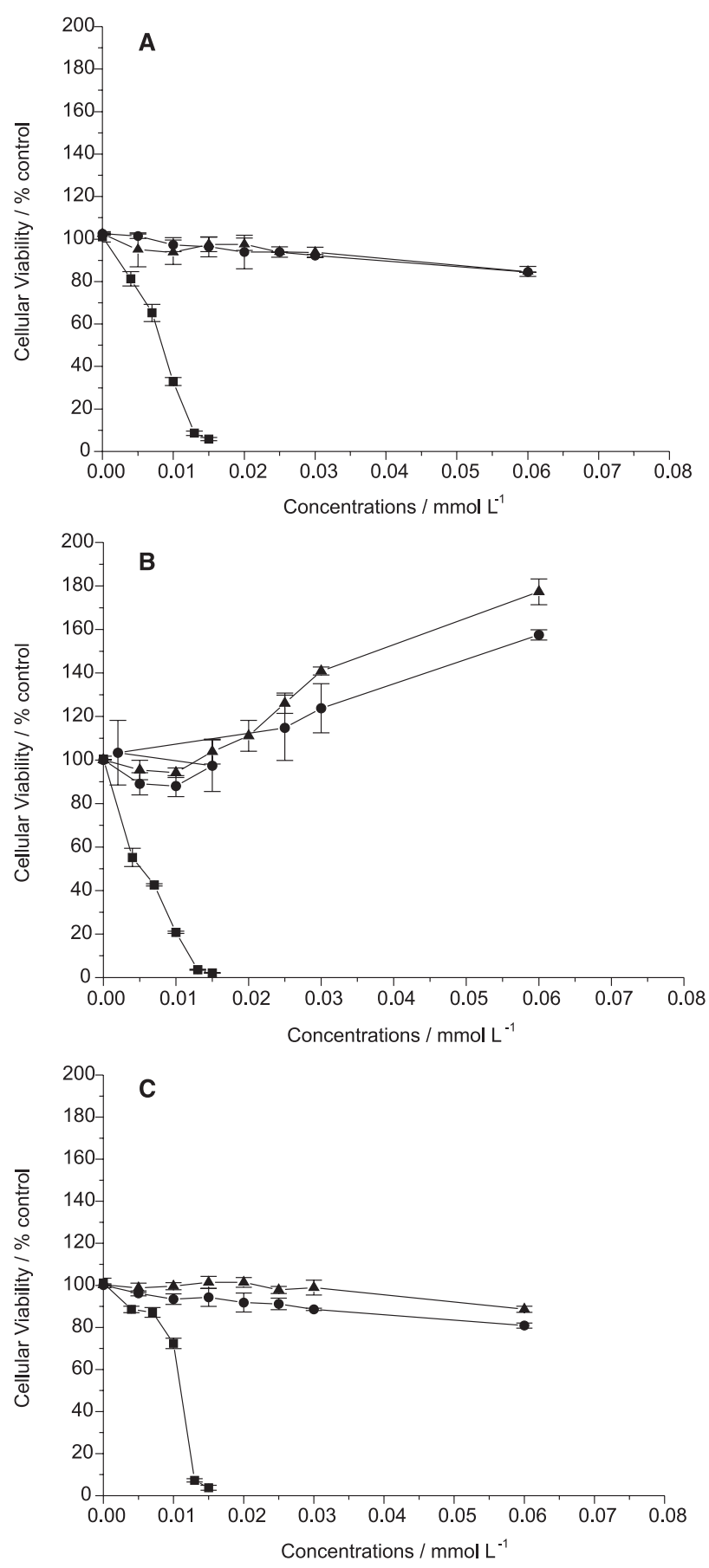

Figure 7. Cytotoxicity of free BBAP, inclusion complexes BBAP/ $\beta$ CD $1: 1$ and BBAP/ $\beta$-CD 1:2 to V79 cells by multiendpoints NAC $(\mathbf{A})$, MTT $(\mathbf{B})$ and NR $(\mathbf{C})$. BBAP $(\mathbf{\square}), \operatorname{BBAP} / \beta-\mathrm{CD} 1: 1(\bullet)$, and $\mathrm{BBAP} / \beta-\mathrm{CD} 1: 2(\mathbf{\Delta})$. 
have indicated that it probably assesses the cytosolic NAD $(\mathrm{P}) / \mathrm{NAD}(\mathrm{P}) \mathrm{H}$ redox balance. The MTT assay also measures cell viability based on endocytosis, a fundamental feature of most living cells. However, various factors affecting the endocytosis of MTT, the exocytosis of MTT formazan, and cellular MTT reductase activity can influence the reduction of MTT. ${ }^{14,15}$ This may have occurred in the inclusion complex.

Figure 8 shows the cytotoxicity of free BBAP and inclusion complexes $1: 1$ and 1:2 acting on $\mathrm{J} 774$ cells by multi-endpoint MTT and NR. Figure $8 \mathrm{~A}$ shows the MTT assay, where the values for free BBAP, BBAP/ $\beta$-CD complexes $1: 1$ and $1: 2$ were $\mathrm{IC}_{50} 0.046,0.066$ and $0.060 \mathrm{mmol} \mathrm{L}^{-1}$, respectively. Meanwhile, in the NR assay (Figure 8B), $\mathrm{IC}_{50}$ values for BBAP in its free form and in BBAP/ $\beta$-CD complex 1:1 and 1:2 were $0.049,0.060$ and $0.059 \mathrm{mmol} \mathrm{L}^{-1}$, respectively. The inclusion complexes were less toxic than free BBAP on J774 macrophages, but the $\mathrm{IC}_{50}$ values were very close $\left(\mathrm{IC}_{50}\right.$ around $\left.0.060 \mathrm{mmol} \mathrm{L}^{-1}\right)$.

The absence of cytotoxic effects induced by the inclusion complexes compared to free BBAP in V79 cells
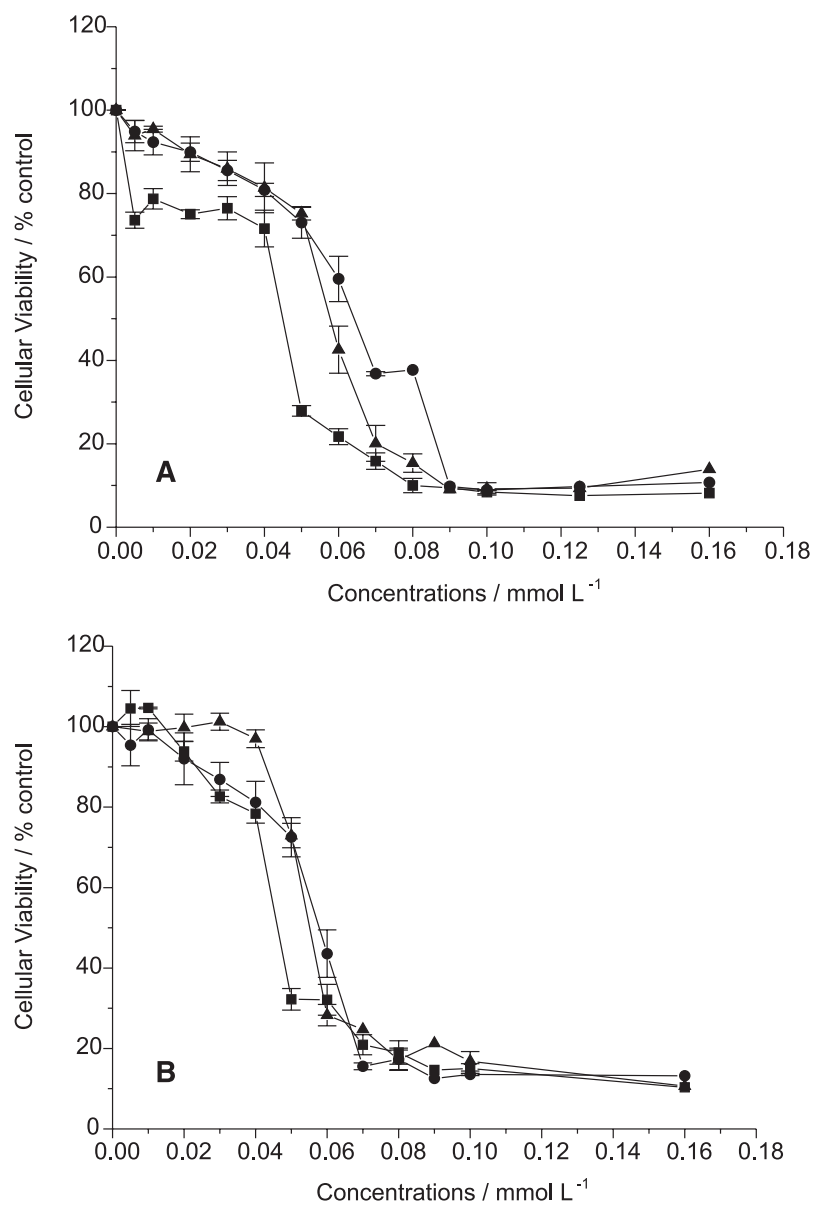

Figure 8. Cytotoxicity of free BBAP, inclusion complexes BBAP/ $\beta$ CD $1: 1$, and $\mathrm{BBAP} / \beta-\mathrm{CD} 1: 2$ to J774 cells by multiendpoints MTT

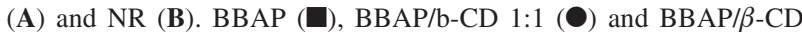
$1: 2(\mathbf{\Delta})$. and reduction of cytotoxicity on $\mathbf{J} 774$ macrophages could be explained by the solubility differences between the complexes and the pure form. The complexes are more hydrophylic than free BBAP and there is a relationship between cellular toxicity, lipophylicity and electrophilicity. It is known that lipophylic substances show more cytotoxic effects than hydrophylic compounds. The toxic effects of the lipophylic compounds are intrinsically related to the changes that they induce in the cell membrane structure. ${ }^{16}$

Several factors can interfere with chemical cytotoxicity including concentration of chemical agents, length of exposure, cell density and cell type. Duration of exposure (T) and drug concentration (C) are related, although CxT is not always a slant. Longer exposure can increase sensitivity beyond that predicted by $\mathrm{CxT}$ due to cell cycle effects and cumulative effect from the agents. ${ }^{14}$ Thus, BBAP and inclusion complexes inhibits $\mathrm{J} 774$ viability in a similar way, but the complexes do not cause cytotoxic effects on V79 cells according to our experimental conditions that could be influenced by intrinsic characteristics of each type of cell culture evaluated.

These data show that, although BBAP/ $\beta$-CD inclusion complexes are more effective than free BBAP on mycobacteria extra and/or intracellularly, the respective concentrations are close to the toxic in vitro concentration. Table 2 expresses the selectivity index (SI) ratio $\mathrm{IC}_{50}$ for J774 macrophages in the MTT assay over MIC for extracellular M. tuberculosis $\mathrm{H} 37 \mathrm{Rv}$ ( $\mathrm{IC}_{50} / \mathrm{MIC}$ ). The SI values determined were 5.75, 8.25 and 7.5 for free BBAP, inclusion complexes BBAP/ $\beta$-CD $1: 1$ and $1: 2$, respectively. Previous reports indicated that, for a drug to be considered effective and good candidate against tuberculosis, its SI should be higher than 10 .

Table 2. Selectivity index (SI) of BBAP, inclusion complex BBAP/ $\beta$-CD $1: 1$ and 1:2 (SI) for antimycobacterial activity in vitro

\begin{tabular}{lccc}
\hline Samples & $\begin{array}{c}\mathrm{MIC} \\
\left(\mathrm{mmol} \mathrm{L}^{-1}\right)\end{array}$ & $\begin{array}{c}\mathrm{IC}_{50}(\mathrm{MTT}) \\
\left(\mathrm{mmol} \mathrm{L}^{-1}\right)\end{array}$ & SI=IC $\mathrm{IC}_{50} / \mathrm{MIC}$ \\
\hline BBAP & 0.008 & 0.046 & 5.75 \\
BBAP/ $\beta$-CD $1: 1$ & $\leq 0.008$ & 0.066 & 8.25 \\
BBAP/ $\beta$-CD $1: 2$ & $\leq 0.008$ & 0.060 & 7.5 \\
\hline
\end{tabular}

$\mathrm{MIC}=$ corresponds to the MIC on M. tuberculosis $\mathrm{H} 37 \mathrm{Rv}$; $\mathrm{IC}_{50}=$ corresponds to the $\mathrm{IC}_{50}$ on $\mathrm{J} 774$ macrophages by the MTT assay; SI $=\mathrm{IC}_{50} / \mathrm{MIC}$.

\section{Conclusions}

An inclusion complex formed between BBAP and $\beta$ $\mathrm{CD}$ by co-evaporation, either at the molar proportion of 1:1 or 1:2 was previously characterized and now observed 
by SEM. In the physical mixtures, no complex was observed. Dissolution studies showed that the inclusion of BBAP in the $\beta$-CD cavity at the molar proportion of $1: 1$ and $1: 2$ increased the release of BBAP, which is important for biological activity.

Biological assays regarding cytotoxicity towards mammalian cells (J774) and towards a permanent lung fibroblast cell line (V79) indicated that BBAP did not exhibit any additional toxic effect with the $\beta$-CD complexes. As to V79 cells, the complexes were not cytotoxic to these cells, compared to the free form. This result is important, since there is a correlation between the $\mathrm{IC}_{50}$ values and the $\mathrm{DL}_{50}$ determined on animals, therefore these complexes would probably be less toxic in vivo than the free form. Cytoxicity assays on $\mathrm{J} 774$ cells were important to determine whether the preparations were toxic to the cells, since mycobacteria are intracellular microorganisms. The BBAP/ $\beta$-CD complexes were more effective (MIC) than the free compound on several tuberculosis strains. Similar behavior of the inclusion complexes BBAP/ $\beta$-CD (1:1 and 1:2) and rifampicin, a front-line antitubercular drug, was observed for $M$. tuberculosis H37Rv growing inside J774 macrophages.

These results indicate that inclusion complexes are better pharmacological formulations in comparison to the free form, since they are less cytotoxic and more effective against mycobacteria. New formulations using other CD derivatives should be investigated, in order to obtain a higher selectivity expressed by SI values.

\section{Acknowledgements}

Financial support from CNPq, PRONEX and FAPESP is gratefully acknowledged.

\section{References}

1. Bibby, D. C.; Davies, N. M.; Tucker, I. G.; Int. J. Pharm. 2000, 197, 1.
2. De Souza, A. O.; Sato, D. N.; Aily, D. C. G.; Durán, N.; J. Antimicrob. Chemother. 1998, 42, 407.

3. Pereira, D. G.; De Castro, S. L.; Durán, N.; Acta Tropica 1998 , 69, 205.

4. De Souza, A. O.; Santos Júnior, R. R.; Ferreira-Júlio, J. F.; Rodrigues, J. A.; Melo, P. S.; Haun, M.; Sato, D. N.; Durán. N.; Eur. J. Med. Chem. 2001, 36, 843.

5. De Souza, A. O.; Hemerly, F. P.; Busollo, A. C.; Melo, P. S.; Machado, G. M. C.; Miranda, C. C.; Santa-Rita, R. M.; Haun, M.; Leon, L. L. Sato, D. N.; De Castro, S. L.; Durán, N.; J. Antimicrob. Chemother. 2002, 50, 629.

6. De Conti, R.; Gimenez, S. M. N.; Haun, M.; Pilli, R. A.; De Castro, S. L.; Durán, N.; Eur. J. Med. Chem. 1996, 31, 915.

7. De Souza, A.O.; Santos Jr., R.R.; Sato, D.N.; Lima, H.O.S.; Andrade-Santana, M.H.; Alderete, J.B.; Faljoni-Alario, A.; Silva, C.L.; Durán, N.; Abstracts of the $29^{a}$ Reunião Anual da Sociedade Brasileira de Bioquímica. Caxambu, Brazil, 2000.

8. Higuchi, T.; Connors, K. A.; Adv. Anal. Chem. Instrum. 1965, 4, 117.

9. Collins, L. A.; Franzblau, s. G.; Antimicrob. Agents Chemother. 1997, 41, 1004.

10. Oh, Y. K.; Nix, D. E.; Straubinger, R. M.; Antimicrob Agents Chemother. 1995, 39, 2104.

11. Cingi, M. R.; De Angelis, I.; Fortunati, E.; Reggiani, D.; Bianchi, V.; Tiozzo, R.; Zucco, F.; Toxicol. In Vitro 1991, 5, 119.

12. Denizot, F.; Lang, R.; J. Immun. Methods 1986, 89, 271.

13. Borenfreund, E.; Puerner, J. A.; J. Tiss. Cult. Meth. 1984, 9, 7.

14. Melo, P. S.; Maria, S. S.; Vidal, B. C.; Haun, M.; Durán, N.; In vitro Cell Rev. Biol. Animal 2000, 36, 539.

15. Melo, P. S.; Durán, N.; Haun, M.; Toxicology 2001, 159, 135.

16. Shrivastava, R.; John, G. W.; Rispat, G.; Chevalier, A.; Massingham, R.; ATLA - Alt. Lab. Anim., 1991, 19, 393.

Received: August 26, 2003

Published on the web: August 24, 2004

FAPESP helped in meeting the publication costs of this article. 